\title{
A new species and a key for the Brazilian species of the genus Heterelmis Sharp, 1882 (Coleoptera: Elmidae, Elminae)
}

\author{
Thiago Tadeu Silva Polizei ${ }^{1}$ \\ 1 Universidade de São Paulo (USP), Museu de Zoologia (MZUSP). Avenida Nazaré, 481, Ipiranga, 04263-000, São Paulo, SP, Brasil. \\ ORCID: 0000-0003-3746-8865. E-mail: thiagopolizei@hotmail.com
}

\begin{abstract}
Heterelmis Sharp, 1882, comprises 22 species and subspecies with 3 species assigned to Brazil so far. Here the forth species, Heterelmis debilis sp. nov. from Brazil, is described and illustrated. The type material is deposited in the Museum of Zoology of the University of São Paulo, São Paulo, Brazil (MZSP) and Natural History Museum, London, UK (NHMUK). Additionally, an identification key with distributional data for Brazilian species is proposed.
\end{abstract}

Keywords. Aquatic beetles; Riffle Beetles; Neotropical; South America; Taxonomy.

\section{INTRODUCTION}

Elmidae is one of the most diverse family of aquatic beetles (Jäch \& Balke, 2008), with more than 1,500 species in 148 genera and two subfamilies (Short, 2018). The genus Heterelmis Sharp, 1882, with 22 species and subspecies, belongs to the subfamily Elminae, distributed from South of United States of America to the South of South America (Jäch et al., 2016). The genus was established by Sharp, 1882 for three species from Guatemala: Heterelmis obesa, H. obscura (type species) and, $H$. simplex. Nowadays the genus holds eighteen species and four subspecies, of which four species are recorded to Brazil (Segura et al., 2012; Segura et al., 2013; Jäch et al., 2016).

According to Passos et al. (2007) the principal diagnostic characteristics of Heterelmis are the body suboval to subparallel; pronotum with anterior margin moderately arcuate; sublateral carina of pronotum complete, extrending from anterior to posterior margin, with or without transverse and/or longitudinal median impression; elytra with a longitudinal carina on sixth and eighth intervals; proepimerum and proepisternum with tomentum; prosternal process long, very wide, with posterior margin rounded to truncated.

In the present work, a new species from South and Southeast regions of Brazil is described and illustrated, and the first identification key for Brazilian species with records of geographic distribution is presented.

\section{MATERIAL AND METHODS}

The identification of the specimens was based on the original descriptions and by comparison with the lectotypes and holotypes deposited in the Muséum National d'Histoire Naturelle (MNHN, Paris, France) and Natural History Museum, London (NHMUK, London, UK).

Mouthparts and male internal genitalia were detached from the specimens and cleared in heated $10 \% \mathrm{KOH}$ for five minutes (Brown, 1972). The mouthparts and the genitalia were observed, drawed and then stored in microvials containing glycerine and attached to the same pin as the specimen. A Leica WILD M10 stereoscopic microscope was used for morphological studies and a ZEISS MRc 5 for photographing the specimens. Photographs and drawings were edited using Adobe Photoshop $\mathrm{CC}^{\circledR}$ and Adobe Illustrator $\mathrm{CC}^{\circledR}$.

The general morphological terminology follows Kodada et al., 2016. The specimen's labels were quoted verbatim. Change of lines are indicated by "/" and the labels separated by "|".

The type material is deposited in the Museum of Zoology of the University of São Paulo, São Paulo, Brazil (MZSP) and Natural History Museum, London, UK (NHMUK).

\section{RESULTS AND DISCUSSION}

\section{Heterelmis debilis sp. nov.} (Fig. 1A-G)

Diagnosis: Body suboval, moderately convex. Head surface covered with micropunctures; antennomeres 3-6 each one with half of length of apical antennomere. Pronotum with a feeble transversal and an oblique impressions on anterior $2 / 5$. Disc of all the five abdominal ventrites 
without tomentum. Aedeagus with parameres strongly acuminate on apex and with a row of setae on internal margin (in ventral view).

Description: General coloration: black with appendages brown. Size range $(n=10)$ Total length 2.1-2.2 mm, greatest width 0.95-1.05 $\mathrm{mm}$.

Head: Partially retractable, without impressions, surface with micropunctures separated from each other by their diameter, each with one seta. Eyes protruding laterally. Antennae almost reaching hind angles of pronotum, filiform with 11 antennomeres, antennomeres 3-6 with half of length of apical ones. Clypeus elongate and concave, with surface covered with punctures and golden long setae. Frontoclypeal suture straight. Labrum reddish-brown, with anterior and lateral margins rounded, surface similar to the clypeus. Mandible (Fig. 1A) with lateral lobe pronounced; apical tooth moderately sharp and prostheca feebly sclerotized with three lobes, apical lobe bilobed. Maxilla (Fig. 1B): cardo wider than long; stipes large, undivided; palpifer present and large; palpi three articulated, galea palpiform and 2-articulated, with long and few setae on apex and sensorial pores laterointernally; lacinia subrectangular with long setae of different sizes anteriorly and externally. Labium (Fig. 1C): gula subrectangular with lateral margins arcuate and with a few setae; mentum with lateral margins concave, anterior angles broadly rounded, anterior margin gradually tapered towards apex; prementum narrow, with apex sinuous; palpi three articulated, palpomeres 1-2 transverse, apical palpomere longer than the basal two combined; ligula wider than long, anterior angles rounded and produced laterally with long setae, ventral surface with rows of hair and circle-like sensilla, (Fig. 1C). Gena with tomentum.

Thorax: Pronotum as long as wide (length $0.7 \mathrm{~mm}$, width $0.8 \mathrm{~mm}$ ), (Fig. 1D). Anterior margin moderately acute, anterior angles acute and protruding, lateral margins sinuous with granules, posterior angles acute, and posterior margin smooth with two prescutellar fovea. Pronotum surface covered with golden setae, with micropunctures separated their own diameter. Sublateral carinae complete, reaching the anterior and posterior margin. Feebly transversal impression in $2 / 5$ of disc, with the posterior portion with a feebly oblique impression towards the scutellum (Fig. 1D). Elytra (Fig. 1E) longer than wide (length $1.35 \mathrm{~mm}$, width $1.0 \mathrm{~mm}$ ), anterior margin arcuate, lateral margin sinuous and apex margin smooth arcuate. Median suture elevated. Sublateral carinae on intervals $\mathrm{VI}$ and VIII, extending $3 / 4$ of elytral length on sixth interval, and $4 / 5$ of elytra length on eighth interval; surface with puncture rows separated by double rows of setae and carinae in each intervals. Scutellum rounded, covered by two rows of golden short setae. Epipleura covered by tomentum (Fig. 1F). Hind wings macropterous. Prosternum broad, as long as wide, with lateral portion covered by tomentum, forming a belt with notosternal suture, reaching the internal $2 / 5$ of hypomera (Fig. 1F). Hypomerum $4 x$ longer than wide, with a deep transversal depression on anterior $2 / 5$. Prosternal process as long as wide, reaching coxae, with posterior margin moderately rounded, surface with micropunctures. Mesoventrite twice as long as wide, with a shallow depression to receive prosternal process, surface similar to prosternum. Metaventrite very broad, $3 x$ wider than long, lateral part covered by tomentum, disc alutaceous with a longitudinal line, with punctures separated from each other by their own diameter. Legs covered by tomentum. Coxae rounded. Trochanter as long as wide. Femora narrowed at the distal margin, only the half-proximal portion covered by tomentum. Tibiae with a row of long fringes of tomentum on half-distal; two rows of short spines on distal third. Elongated tarsus, with setae, apical tarsomere smaller than the basal four combined. Claws large and stout.

Abdomen: Five ventrites (Fig. 1F). Margins moderately arcuate. Surface covered by micropuctures and short setae, separated from each other by their own diameter, tomentum absent only in median portion. First ventrite with a pair of carinae medially, extending from anterior to posterior margin. Fifth ventrite with apex rounded, lateral margin with a shallow depression.

Genitalia: (Fig. 1G). Phallobase twice as long as wide. Parameres reaching the posterior $3 / 4$ of penis length, twice wider at base than at apex, feebly sharp on apex, inner margin with a row of long setae. Penis as long as phallobase, $3 x$ as long as wide, strongly constricted at apex; basolateral apophyses $4 x$ longer than wide; fibula restricted to the anterior half part.

Female: External morphology similar to male except by the absence of long setae on tibiae.

Etymology: The specific epithet debilis refers to the feeble transversal and oblique impressions on pronotum.

Type locality: Nova Teutônia (municipality of Seara), Santa Catarina State, Brazil.

Male holotype: Labels: $\sigma^{*}$ | Holotype | Nova Teutônia S.C. / Brasil / V.1966 / Fritz Plaumann leg. | MZSP 35546. (MZSP).

Paratypes: 92 specimens: Brazil, Minas Gerais: Itacarambi / (Caverna Olhos d'Água) / 10.VII.1993 / E. Trajano leg. (2 specimens, MZSP). Brazil, Minas Gerais: Cambui / (Sitio Cachoeirinha, Córrego) / 01.V.2017 / S. Vanin leg. (1 specimen, MZSP). Brazil, São Paulo / Campos do Jordão / (Pq. Estadual), 26.IIl.1987 / L.G.Oliveira \& C.G. Froehlich leg. (4 specimens, MZSP). Brazil, São Paulo / Salesópolis (Estação Biológica / de Boracéia, Rib. Venerando) / 27-28, Maio, 1965 / C.G. Froehlich leg. (1 specimen, MZSP). Brazil, São Paulo / Ribeirão Grande (Faz. Intervales) / 09.XI.1983, Froehlich \& Paprocki leg. (10 specimens, MZSP). Brazil, Santa Catarina / Anita Garibaldi I.1940 / Col. Dirings (3 specimens, MZSP). Brazil, Santa Catarina / Nova Teutônia, V.1966 / Fritz Plaumann leg. (60 specimens in MZSP; 11 specimens in NHMUK). 

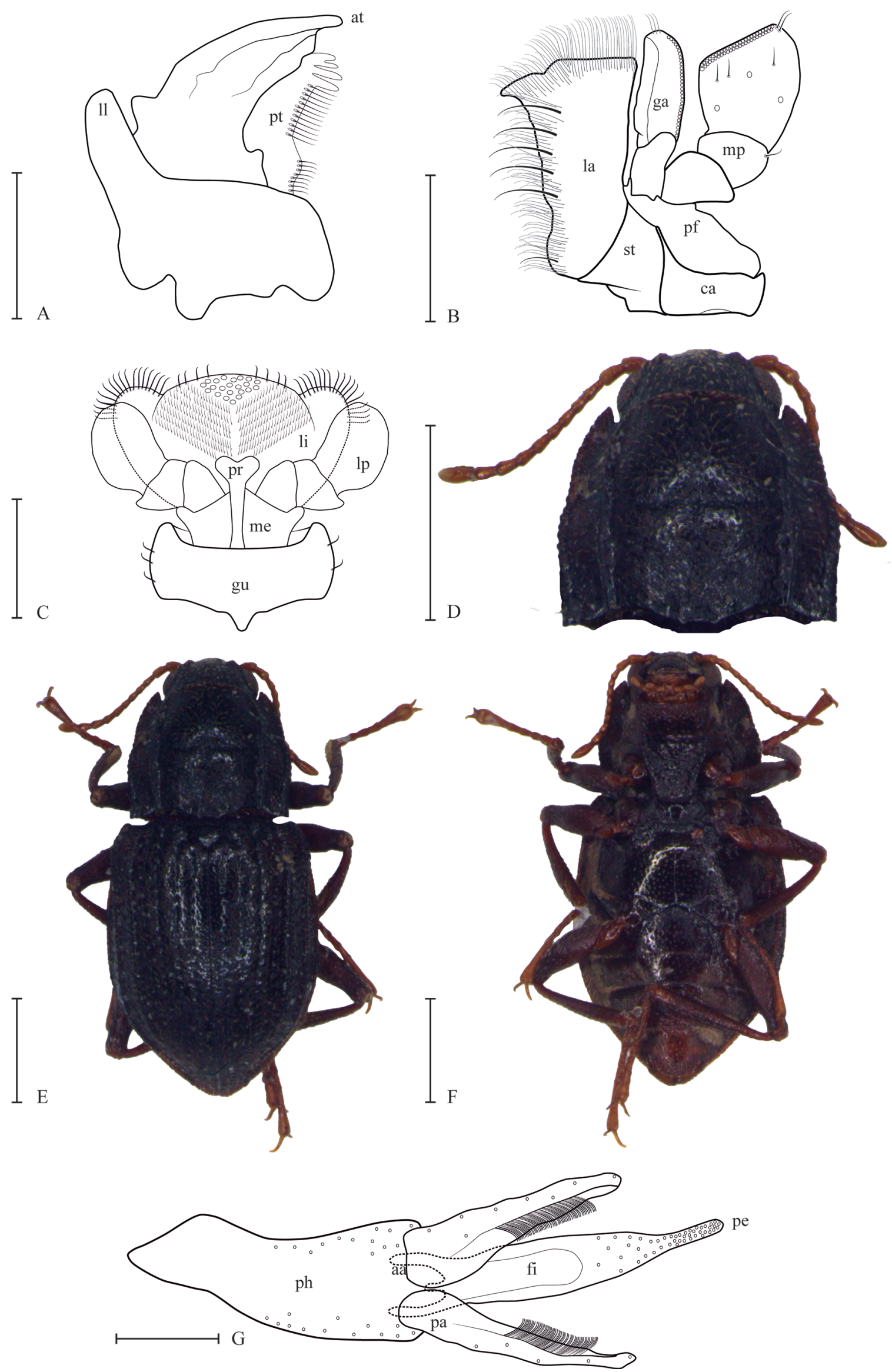

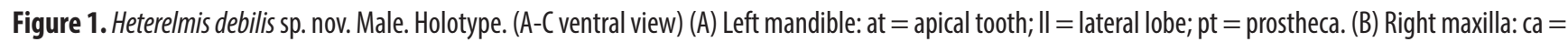
cardo; ga = galea; la = lacinia; $\mathrm{mp}=$ maxillary palp; $\mathrm{pf}=$ palpifer; $\mathrm{st}=$ stipes. (C) Labium: $g u=$ gula; lp = labial palp; li = lígula; $m e=$ mentum; $p r=p r e m e n t u m$. (D) Dorsal view of head and pronotum. (E) Habitus: dorsal view. (F) Habitus: ventral view. (G) Ventral view of aedeagus: aa = basolateral apophyse of penis; $\mathrm{fi}=$ fibula; $p a=$ paramere; $p e=$ penis; $p h=$ phallobase. Scale bars: $(A-C ; G)=0.1 \mathrm{~mm},(D-F)=0.5 \mathrm{~mm}$. 
Additional material: 10 specimens: Brazil, Rio de Janeiro / Nova Friburgo, Lumiar / 15.XI.2008 / B.H.L. Sampaio leg. (Entomological Collection Professor José Alfredo Pinheiro Dutra, Department of Zoology, Federal University of Rio de Janeiro (DZRJ)).

Comments: Heterelmis debilis sp. nov. can be easily differentiated from any other species of the genus by a feeble transversal and an oblique impressions on pronotum. The new species resembles $H$. obscura by the body shape and the presence of a transversal and an oblique impressions on pronotum but the latter has stronger impressions on pronotum, the body is more elongated, besides the differences in the male genitalia. It is also similar to H. apicata (Grouvelle, 1896) by the pattern of the male genitalia, however the aedeagus of the latter is thiner, without row of setae on parameres and its pronotum does not present any kind of impression.

Heterelmis obscura was described by Sharp (1882) to Guatemala and Grouvelle (1889) recorded it from Brazil (Santa Catarina State). According to Grouvelle, these specimens are less elongated than the Central American specimens. The type lectotype of $H$. obscura and the Grouvelle's collection, both housed at MNHN (Paris), were studied. The Brazilian specimens of "H. obscura" det. by Grouvelle (1889) are actually a new species, here described and named Heterelmis debilis sp. nov. For this reason, $H$. obscura has its geographic distribution restricted to Costa Rica, Guatemala, Mexico and Peru (Jäch et al., 2016).

\section{Identification key to the Brazilian species of Heterelmis Sharp, 1882}

1. Pronotum with longitudinal, transversal or oblique impressions............2

1. Pronotum without impressions

2. Pronotum with only one longitudinal impression. Santa Catarina and São Paulo State H. dubia Grouvelle, 1889

2. Pronotum with a feeble transversal and an oblique impressions. Minas Gerais; Rio de Janeiro; Santa Catarina and São Paulo State

.H. debilis sp. nov.

3. Body oval, strongly convex, sublateral carinae on pronotum arcuate, trochanter without tomentum. Rio de Janeiro State...

H. gibbosa (Grouvelle, 1889)

3'. Body suboval, moderately convex, sublateral carinae on pronotum acuminate on apex, pro and mesotrochanter with tomentum. Santa Catarina and São Paulo State H. limnoides Hinton, 1936

\section{ACKNOWLEDGMENTS}

Thanks to Fundação de Amparo a Pesquisa do Estado de São Paulo (FAPESP, 2015/17064-7 and 2016/21184-0), Sônia Casari (MZSP) for their suggestions on this paper and Rafael Souza (MZSP) for the support with the drawings. I am grateful to the Coleoptera curatorial team (NHMUK and MNHN) for their support.

\section{REFERENCES}

Brown, H.P. 1972. Aquatic dryopoid beetles (Coleoptera) of United States. Biota of Freshwater ecosystem, identification manual no 6. Ohio, U.S. Environmental Protection Agency.

Grouvelle, A. 1889. Nouvelles espèces d'Helmides. Annales de la Société Entomologique de France, Ser. VI, 8[1889]: 393-410, pls. VII-VIII.

Grouvelle, A. 1896. Descriptions de Dryopides (Parnides) et Helmides nouveaux. Notes from the Leyden Museum, 18(1): 33-52.

Hinton, H.E. 1936. Descriptions and figures of new Brazilian Dryopidae (Coleoptera). Entomologist, 69: 283-289.

Jäch, M.A. \& Balke, M. 2008. Global diversity of water beetles (Coleoptera) in freshwater. Hydrobiologia, 595: 419-442.

Jäch, M.; Ján, K.; Michaela, B.; William, S. \& Fedor, Č. 2016. Coleoptera: Elmidae and Protelmidae. World catalogue of insects, Leiden, Brill. v. 14.

Kodada,J.; Jäch, M.A.\& Fedor, Č. 2016. 19.2. Elmidae Curtis, 1830, pp. 561-589. In: Beutel, R.G. \& Leschen, R.A.B. (Eds.). Handbook of Zoology, Volume IV (Part 38), Coleoptera, Beetles, Volume 1: Morphology and Systematics (Archostemata, Adephaga, Myxophaga, Polyphaga partim), 2.ed. Berlin, Walter de Gruyter. xvii + 684p.

Passos, M. I. S.; Nessimian, J.L. \& Ferreira Jr., N. 2007. Chaves para identificação dos gêneros de Elmidae (Coleoptera) ocorrentes no Estado do Rio de Janeiro, Brasil. Revista Brasileira de Entomologia, 51(1): 42-53.

Segura, M.O.; Passos, M.I.S.; Fonseca-Gessner, A.A. \& Froehlich, C.G. 2013. Elmidae Curtis, 1830 (Coleoptera, Polyphaga, Byrrhoidea) of the Neotropical region. Zootaxa, 3731(1): 1-57.

Segura, M.0.; Valente-Neto, F. \& Fonseca-Gessner, A.A. 2012. Checklist of the Elmidae (Coleoptera: Byrrhoidea) of Brazil. Zootaxa, 3260: 1-18.

Sharp, D. 1882. Fam. Parnidae, In: Godman, F.D. \& Salvin, 0. (Eds.). Biologia Centrali-Americana, Insecta, Coleoptera 1(2). London, 1882-1887. p. 119-140, 1 pl.

Short, A.E.Z. 2018. Systematics of aquatic beetles (Coleoptera): current state and future directions. Systematic Entomology, 43(1): 1-18. 